\title{
An Empirical Study on Determinants of Sustainable Development of Coastal Eco-tourism
}

\author{
Wuling Zeng, Keyi Wang, Yingchao Jia \\ School of Management Dalian University of Technology Dalian, China
}

\begin{abstract}
With the popularity of eco-tourism, the sustainability of its development has become a focus problem in both theoretical and practical fields. Based on existed research, the study summarized the determinants of sustainable development of coastal eco-tourism as four aspects, that are resource environment, economic environment, social environment and management control. And we tested the path and degree of various factors' influence through the empirical method. Finally, we made suggestions on the development of coastal ecotourism for related departments and enterprises.
\end{abstract}

Index Terms: Coastal eco-tourism; sustainable development; determinant factors;

(C) 2012 Published by MECS Publisher. Selection and/or peer review under responsibility of the International Conference on E-Business System and Education Technology

\section{Introduction}

With the acceleration of urbanization, people are not satisfied with humanities buildings, playgrounds and other forms of landscape any more and are tired of aesthetic of these landscapes. So eco-tourism which promotes to return to nature and enjoy the beauty becomes the choices of the public. However, even in the guidance of low-damage concept, the influx of a large number of tourists and the development of tourism resources are still cause pressure and threat on environment. Once scientific, unified planning and management are lacked, the balance of ecological environment and the sustainable development of coastal eco-tourism will suffer large damage, thus affecting the sustainable development of coastal areas' society and economy[1]. Therefore, it is very necessary to study the sustainable development of coastal eco-tourism. Only when the determinants related to the sustainable development of coastal eco-tourism are identified, could a scientific basis to tourism plan and management be provided and then guide the tourism activities of government departments, tourism operators and tourists, so as to achieve the unity of man and nature, the harmony of man and coastal environment, and ultimately to realize the sustainable development of environment, society, economy and culture.

\section{THE RESEARCH CONTENT}

The main content of this study is to identify the determinants of sustainable development of coastal eco-tourism and affirm the impact path and degree of various factors.

Corresponding author:

E-mail address: 
Tourism itself is a highly open industry. Coastal eco-tourism system constantly contacts and exchanges with external substances and personnel. Besides their resource endowment the sustainability of their development highly depends on the external environment. Based on "social - economic - environmental three-component model" in sustainable development theory and on the consideration of reasonable management plan is the potential to maintain the sustainable development of coastal eco-tourism and is the determinant to promote economic, environmental and social benefits, four types of determinants of sustainable development of coastal eco-tourism are summarized by this study - management control, resource environment, economic environment and social environment[2]. Based on its impact degree on sustainable development of coastal eco-tourism, the study divides these four types into core factors and environmental factors.

Core factors include basic resource condition which could determine the sustainable development of coastal eco-tourism and scientific management and monitoring system which could maintain the potential of sustainable development of coastal eco-tourism. Basic resource condition not only contains natural resources of coastal eco-tourism area, ecological carrying and resilience capacity of the ecological environment, but also contains humanities buildings built for development tourism resource. Despite the idea of experience nature and protecting the environment is the emphasis in the process of develop eco-tourism, basic service facilities are also necessary. Meanwhile, humanities facilities' ecologicalization and the coherence with nature resources are very important in order to ensure sustainable development. In addition, natural resources just provide basic condition to develop coastal eco-tourism, sustainable development of it also needs scientific planning and monitoring. If the basic eco-tourism resources are developed without any order, abuse and lack of effective management, even fine resources will also be destroyed. Management and monitoring mainly include regulations of resource exploit, public education of environment protection and investment on personnel, scientific research, and environmental regulations related to sustainable development of ecological tourism

Environmental factors include economic environment and social environment of coastal eco-tourism. Both of them are relatively independent environment related to coastal eco-tourism system and constitute the basic external environment of coastal eco-tourism industry together. First, the economic development and growth rate determines the level of people's consumption, thus affecting consumers' choice. In addition, the economy of coastal tourist areas will significantly affect the number of tourists because of business, trade and other affairs. Economic development of the tourism industry determines carrying capacity of regional tourism directly, while the growth of tourism industry determines resource investment needed in the process of tourism industry development and sustainable development when the number of visitors increases by a certain percentage. Second, social environment of the coastal ecological tourism constitute soft environment support of tourism development. It includes the situation of social stability, transport, health and other situation of social security as well as infrastructural facilities. Besides these, environmental awareness and environmental participation of local residents also affect the sustainable development of coastal eco-tourism to some extent.

In accordance with the above discussion, the study divides determinants of sustainable development of coastal eco-tourism into four aspects, which are resource environment, economic environment, social environment and management control. Among them, resource environment includes natural resource endowment and civil facilities coordination two dimensions; economic environment includes social economy and tourism industry economy two dimensions; social environment includes social security and stability and social environmental protection awareness two dimensions; management control includes resource exploiting regulations, environmental protection investment and environmental publicity education three dimensions.

\section{RESEARCH METHODS AND DATA ANALysis}

\section{1 Research Methods}

The study adopts questionnaire survey method. The criterion for setting down specific items lies in two aspects. One is referring to relevant policies and regulations and extracting from them. The other is visiting some experts and practitioners and asking them for recommendations. After that, 47 items are set down. The survey data of the research come from eco-tourism and service industry professionals of Dalian City and its surrounding cities, counties, and districts. In recent years, the government of Dalian City strongly supports the development

2010 Dalian Social Science Fund (10DLSK126). 
of tourism industry and proposes a way of the coastal eco-tourism. Now Dalian City has developed into a famous coastal eco-tourism city with excellent reputation because of its favorable geographical location as well as reasonable development plan for years. So the survey of Dalian coastal ecological tourism is of representative significance. The study uses SPSS15.0 and Lisrel8.7 to process the survey data.

\section{2 Exploratory Factor Analysis}

For the four dimensions of sustainable development of coastal eco-tourism the study uses principal component analysis in the process of exploratory factor analysis.

KMO values of the four dimensions are all above 0.7. It means we can do exploratory factor analysis[3]. The results of exploratory factor analysis show that, resource environment is divided into two dimensions, and its cumulative explained variance is 62.039\%; economic environment is divided into two dimensions, and its cumulative explained variance is $74.305 \%$; social environment is divided into two dimensions, and its cumulative explained variance is $63.230 \%$; management control is divided into three dimensions, and its cumulative explained variance is $73.448 \%$. Three items of economic environment and social environment with factor loading less than 0.5 are removed, which are "the proportion travel industry accounts for tertiary industry", "natural population growth", and "the incidence of criminal cases". The factor loadings of remaining items are all greater than 0.5, have no significant cross-factor distribution, and have good construct validity. The results of exploratory factor analysis are accordance with the above analysis, and validate the definition of the determinants of sustainable development of coastal eco-tourism.

TABLE I : EXPLORATORY FACTOR ANALYSIS OF RESOURSE ENVIRONMENT

\begin{tabular}{|l|l|l|}
\hline \multirow{2}{*}{ Items } & \multicolumn{2}{|c|}{ Factors } \\
\cline { 2 - 3 } & \multicolumn{1}{|c|}{ Fa1 } & \multicolumn{1}{|c|}{ Fa2 } \\
\hline construction of eco-designed tourist trail & 0.870 & \\
\hline oriented public information signs & 0.829 & \\
\hline the scale of ecological infrastructure & 0.814 & \\
\hline the scale of green space & 0.756 & \\
\hline The coordination of buildings and environment & 0.556 & \\
\hline the scale of natural landscape & & 0.794 \\
\hline the coordination between cultural landscape and natural landscape & & 0.777 \\
\hline the diversity of species & & 0.765 \\
\hline Ecological carrying capacity & & 0.736 \\
\hline Resilience of the ecological environment & & 0.629 \\
\hline The number of high-level tourism resources & & 0.513 \\
\hline
\end{tabular}


TABLE II : EXPLORATORY FACTOR ANALYSIS OF ECONOMIC ENVIRONMENT

\begin{tabular}{|l|l|l|}
\hline \multirow{2}{*}{ Items } & \multicolumn{2}{|c|}{ Factors } \\
\cline { 2 - 3 } Annual per capita GDP growth & \multicolumn{1}{|c|}{ Fb1 } & F 2 \\
\hline GDP annual growth & & \\
\hline infrastructure investment per annum & & \\
\hline fiscal revenue growth of region & 0.798 & \\
\hline Annual disposable income growth per capita & 0.761 & \\
\hline reception capacity of hotels, guesthouses, travel agencies & & \\
\hline Average annual change of tourism total revenue & 0.706 & \\
\hline the number of annual tourists & & 0.853 \\
\hline the proportion of tourist industry in regional & & 0.812 \\
\hline
\end{tabular}

\section{TABLEIII: EXPLORATORY FACTOR ANALYSIS OF SOCIAL ENVIRONMENT}

\begin{tabular}{|l|l|l|}
\hline \multirow{2}{*}{ Items } & \multicolumn{2}{|c|}{ Factors } \\
\cline { 2 - 3 } & \multicolumn{1}{|c|}{ Fc1 } & \multicolumn{1}{|c|}{ Fc2 } \\
\hline $\begin{array}{l}\text { the impact of experts, conservation organizations, local community } \\
\text { and tourists's views on coastal eco-tourism operators }\end{array}$ & 0.901 & \\
\hline Number of eco-tourists involved in environmental protection & 0.892 & \\
\hline Number of tourism employment to local residents & 0.805 & \\
\hline $\begin{array}{l}\text { Awareness of ecological and environmental protection of local } \\
\text { residents }\end{array}$ & 0.778 & \\
\hline $\begin{array}{l}\text { average years of schooling per capita } \\
\text { condition of local medical security }\end{array}$ & 0.553 & \\
\hline the proportion of social security expenditure in local GDP & & 0.780 \\
\hline the proportion of unemployed persons & & 0.765 \\
\hline number of commercial network and centres & & 0.761 \\
\hline
\end{tabular}


TABLEIV : EXPLORATORY FACTOR ANALYSIS OF MANAGEMENT CONTROL

\begin{tabular}{|c|c|c|c|}
\hline \multirow{2}{*}{ Items } & \multicolumn{3}{|c|}{ Factors } \\
\hline & Fd1 & Fd2 & Fd3 \\
\hline the use of pollution-free detergent & 0.924 & & \\
\hline the use of energy-saving facilities & 0.849 & & \\
\hline the use of low-pollution vehicles & 0.847 & & \\
\hline the use of ecological building materials & 0.797 & & \\
\hline range defined of seaside resort & 0.768 & & \\
\hline Safe disposal of waste & 0.748 & & \\
\hline $\begin{array}{l}\text { raw materials of travel goods excluding rare species endangered } \\
\text { species }\end{array}$ & 0.720 & & \\
\hline local environmental laws and regulations & & 0.883 & \\
\hline the number of environmental protection professionals & & 0.785 & \\
\hline support of local government to coastal eco-tourism & & 0.744 & \\
\hline the formulation of environmental management system & & 0.726 & \\
\hline Coastal Environmental Protection training for tour operators & & & 0.807 \\
\hline propaganda and education on coastal ecological knowledge & & & 0.757 \\
\hline the proportion of professionals in tour operators & & & 0.743 \\
\hline the formulation of code of conduct for tourist & & & 0.561 \\
\hline
\end{tabular}

\section{ANAlysis of IMPACT PATH AND EXTENT}

The study uses structural equation model (SEM) to test the foregoing dimensions' impact path and impact extent of the sustainable development of coastal eco-tourism. T values of all observed variables’ factor loadings are greater than 5, higher than the minimum standard 2[4].

The study adopts maximum likelihood method of the software Lisrel 8.7 to estimate the data. Table 1 shows the 11 fitness indexes of the model and most of them have reached the standards of goodness, that means confirmatory factor analysis model have a good fitting degree with the data[5]. 
TABLE. V : Fitness IndeXes of THE Structural Equation Model

\begin{tabular}{|l|l|l|l|l|}
\hline \multirow{2}{*}{$\begin{array}{l}\text { Fitness } \\
\text { Indexes }\end{array}$} & \multicolumn{4}{|c|}{ Index Values } \\
\cline { 2 - 5 } & $\begin{array}{c}\text { Resource } \\
\text { Environment }\end{array}$ & $\begin{array}{c}\text { Economic } \\
\text { Environment }\end{array}$ & $\begin{array}{l}\text { Social } \\
\text { Environment }\end{array}$ & $\begin{array}{l}\text { Management } \\
\text { Control }\end{array}$ \\
\hline X2/df & 3.60 & 8.01 & 4.26 & 2.93 \\
\hline GFI & 0.84 & 0.91 & 0.95 & 0.82 \\
\hline AGFI & 0.76 & 0.79 & 0.82 & 0.75 \\
\hline RMR & 0.057 & 0.078 & 0.064 & 0.057 \\
\hline RMSEA & 0.045 & 0.035 & 0.044 & 0.031 \\
\hline NFI & 0.86 & 0.89 & 0.92 & 0.93 \\
\hline NNFI & 0.86 & 0.86 & 0.85 & 0.94 \\
\hline CFI & 0.89 & 0.90 & 0.91 & 0.95 \\
\hline IFI & 0.89 & 0.90 & 0.91 & 0.95 \\
\hline PNFI & 0.67 & 0.64 & 0.63 & 0.77 \\
\hline PGFI & 0.55 & 0.51 & 0.55 & 0.59 \\
\hline
\end{tabular}

As to resource environment, the path coefficients of natural resource endowment and civil facilities coordination are respectively 0.76 and 0.75 , thus indicating that the two dimensions are equally important for the resource environment of the sustainable development of coastal eco-tourism. Natural resource endowment provides the basis for the development of coastal eco-tourism, but civil facilities coordination is also very important especially humanities facilities' ecologicalization.

As to economic environment, the path coefficients of social economy and tourism industry economy are respectively 0.56 and 0.65 , thus indicating that the economy of tourism industry has more direct impact on coastal eco-tourism development while social overall economy just provides the basic conditions for the development and has less significant impact on it.

As to social environment, the path coefficient of social environmental protection awareness is 0.89 , showing the importance of it for sustainable development of coastal eco-tourism, while that of social security and stability is 0.52 .

As to social environment, the path coefficients of environmental protection investment, resource exploiting regulations and environmental publicity education are 0.86, 0.57, and 0.96 respectively, showing that environmental protection investment and environmental publicity education have strong impact on sustainable development of coastal eco-tourism while resource exploiting regulations has a less significant impact on it due to the differences between regulations and implementation.

\section{Conclusion and Future Research}

The Research did a preliminary exploration on determinants of sustainable development of coastal eco-tourism. The Research based on the existing studies of sustainable development and proposed four aspects which affect sustainable development of coastal eco-tourism. The four aspects are: resource environment, economic environment, social environment and management control. The research also examined the divide of dimensions through further empirical studies and made the following conclusions:

(1) The sustainable development of coastal eco-tourism are mainly affected by resources, economy, society and management control.

(2) The development of coastal eco-tourism needs to pay attention to humanities facilities' ecologicalization on the basis of natural resources. 
(3) Economic conditions of tourism industry, social environmental awareness and public participation play important roles in the sustainable development of coastal eco-tourism.

(4) The focuses of management control are: ensuring the investment of ecological facilities and environmental publicity education, maintaining and enhancing the sustainable development of coastal eco-tourism and really play the role of publicity education.

Due to factors such as time limited and resources constraint, although the study on determinants of sustainable development of coastal eco-tourism referred to a large number of existing research and information, it may be still not comprehensive enough. In addition, when it comes to questionnaire distribution especial the quantity and the objects, it may also have limitation. We look forward improvement of these issues in the further study.

\section{References}

[1] R. Rong, "Study on the Index System of Sustainable Development of Coastal Ecotourism”, unpublished, in chinese

[2] H.L. Hua, Y.J. Pan, “A Review on the Assessment Methods of Sustainable Development” J. Kunming.China, vol.3, pp23-28., Journal of Yunnan Normal University, May 2005, in chinese

[3] Malhotra Y.,Galletta D. "Extending the Technology Acceptance Model to Account for Social Influence:Theoretical Bases and Empirical Validation”. Proceedings of the Hawaii International Conference on System Sciences,1999, pp235-252.

[4] Mueller R O.Basic Principles of Structural Equation Modeling:an Introduction to Lisrel and EQS.New York:Spring-Over-flag, 1996.pp66-77

[5] W.T. Zhang, SPSS11 statistics analysis course,Beijing Hope Electronic Press, 2002,pp151-172, in chinese 